\title{
Л.С. Васильченко
}

\section{ІНТЕГРОВАНІ МАРКЕТИНГОВІ КОМУНІКАЦІЇ ПІДПРИЕМСТВА: ГЕНЕЗИС ТА ЕТАПИ СТАНОВЛЕННЯ}

\begin{abstract}
Анотація. У статті проаналізовано етимологію поняття «комунікації» та досліджено різноманітні підходи і визначення иієї дефініції. Встановлено, щьо особливе місие серед масових комунікацій займають маркетингові комунікачії, які являють собою прочес передачі інформачії про продукт і його властивості безпосередньо иільовій аудиторії. Наведено основні теорії та концепиії, що формують предметні області дослідження маркетингових комунікацій, досліджена нова концепція комунікаційного маркетингу - інтегровані маркетингові комунікаиії, що є інструментом маркетингової адаптації діяльності підприємств до змін зовнішнього середовища. Також охарактеризовано причини підвищення ефективності маркетингових комунікаиій при їх інтеграиіі, наведено головні переваги використання інтегрованих маркетингових комунікаиій. Метою статті $є$ дослідження етапів становлення інтегрованих маркетингових комунікацій, об'єктом - процес становлення і розвитку інтегрованих маркетингових комунікацій підприємства.

Ключові слова: комунікації, маркетингові комунікації, інтегровані маркетингові комунікації, еволюиія маркетингових комунікації, етапи становлення маркетингових комунікацій.
\end{abstract}

Актуальність проблеми. Пройшовши достатньо довгий період у своєму розвитку, сучасний маркетинг сформувався у визнану теорію ефективної економічної діяльності в конкурентному середовищі та затребувану практикою систему задоволення потреб ринку. Розширення його меж і масштабів призводить до нового наповнення змісту категорії маркетингу, зміни об'єктів і суб' єктів та удосконалення інструментарію, а раціональну взаємодію суб'єктів в ринковому просторі неможливо забезпечити без надійно налагоджених елементів комунікацій. На сьогодні все більше компаній приймає концепцію інтегрованих маркетингових комунікацій, що зумовлює необхідність та актуальність проведення аналізу їх становлення, визначення логіки руху від окремих інструментів до інтегрованої системи, з'ясування основних принципів інтеграції та виявлення головних тенденцій подальшого розвитку.

Аналіз останніх джерел, досліджень і публікацій. Аналіз досліджень та публікацій наукових джерел показує, що питання сутності маркетингових комунікацій, їх місця та ролі в маркетинговій діяльності знаходяться в центрі уваги вітчизняних та зарубіжних вчених: Почепцова Г. Г. [3], Карпенко Н. В., Яловеги Н. І. [4], Мак-Квейла Д. [6], Котлера Ф. [11], Барнета Д., Моріарті С.[12], Примак Т. О. [14; 21] та ін.

Мета дослідження. Метою статті є дослідження сутності та еволюції розвитку маркетингових комунікацій, етапів становлення інтегрованих маркетингових комунікацій та переваг їхнього використання.

Викладення основного матеріалу дослідження. Поняття «комунікація» багатоаспектне, існує безліч визначень цього широкого і всеосяжного за своїм значенням терміну, який використовується в різних сферах життя і діяльності. Комунікація (як зв'язок і спілкування) - від латинського «Communicatio» означає повідомлення, передача i від «communis» процес обміну інформацією (фактами, ідеями, поглядами, емоціями) між двома або більше особами, спілкування за допомогою вербальних і невербальних засобів, тобто прийнятий в дослідженнях термін, що позначає процес передавання та одержання інформації, забезпечуючи єдність i спадкоємність людської діяльності [1, с. 545].

Сьогодні існує велика кількість різних підходів і визначень до поняття «комунікація». Зупинимося на найбільш широко використовуваних визначеннях цієї дефініції. Так, Завадський Й. М. пропонує під терміном «комунікація» розуміти «... процес передачі повідомлення, що включає, як правило, шість елементів: джерело, повідомлення, канал комунікації, одержувача, а також процеси кодування і декодування [2, с. 24]. Почепцов Г. В. у своїй науковій праці «Теорія комунікації» під комунікацією розуміє процеси перекодування інформації із вербальної в невербальну сферу і навпаки [3, с.15]. Слід погодитися з визначенням Карпенко Н. В., Яловеги Н. І., які визначають комунікацію 
як організацію процесу зв'язку індивідів та суспільства через зустрічне переконання і спонукання для створення гармонійних, взаємовигідних соціально-економічних відносин між ними [4, с. 8].

Автор поділяє думку Дуцик Д., яка у своїй роботі «Політична журналістика» виокремлює чотири основні трактування терміну «комунікація»: 1) універсальне, як спосіб зв'язку будь-яких об'єктів матеріального та духовного світу; 2) технічне, як шлях зв'язку одного місця з іншим, засіб передачі інформації та інших матеріальних і духовних об'єктів з одного місця в інше; 3) біологічне, широко використовуване в етології при вивченні сигнальних способів зв'язку тварин, птахів, комах тощо; 4) соціальне, за якого комунікація використовується на позначення та для характеристики багаточисельних зв'язків та відносин, які виникають у людському суспільстві [5, с.52].

Особливе місце серед масових комунікацій займають маркетингові комунікації, які представляють процес передачі інформації про продукт і його властивості безпосередньо цільовій аудиторії.

Для пізнання ролі комунікацій у формуванні споживчої поведінки ми вважаємо доречним звернутися до теорії відтворення.

Відомо, що з макроекономічних позицій національні економіки розвинених країн, i, у певній мірі, уся світова економіка в першій половині XX ст. характеризувалися як епоха індустріального суспільства; у другій половині - як постіндустріальна.

Науково-технічна революція надала товаровиробникам можливість насичувати ринки усе більш різноманітними видами товарів і послуг.

Для індустріальної епохи розвиток продуктивних сил забезпечувався відповідною економічною політикою, метою якої виступали максимізація обсягів виробництва й прагнення конкуруючих товаровиробників до забезпечення домінуючої частки ринку.

У класичній політичній економії XVII-XX ст. із усіх фаз процесу відтворення (виробництво, розподіл, обмін, споживання) домінуюче місце відводилося фазі виробництва. Іншими словами, класична економічна теорія пояснювала необхідність і правомірність проведення економічної політики товаровиробників, що базується на нематеріалістичній філософії розуміння суспільних відносин.

Відмітною рисою $\mathrm{XX}$ століття стало доповнення постіндустріальної економіки іiі інформаційним компонентом, зростанням iї ролі в економічних відносинах. Це було обумовлено тим, що саме із другої половини XX ст. у ринкових економіках, у першу чергу, розвинених країн, виявилася наростаюча криза надвиробництва (збуту), з розширенням номенклатури товарів i послуг, обсяги виробництва яких перевищували обсяг споживчого попиту на них. Як наслідок, ринки стали поступово трансформуватися з ринків продавців у ринки покупців (споживачів).

3 позицій маркетингу домінуючою фазою відтворювального циклу в рамках сучасної економічної науки стала розглядатися фаза споживання. Це пояснюється тим, що ринковим сигналом для початку чергового циклу відтворювального процесу для товаровиробників $\epsilon$ наявність попиту на вироблену ними продукцію, виявлення якого відбувається за допомогою одержання відповідної інформації в порядку зворотного зв'язку: від споживача до виробника, що в маркетингу розглядається як однією із ключових умов формування їх взаємин.

Звідси випливає, що в маркетингу відбувається своєрідний перерозподіл ролі його елементів на користь зростання ролі інформаційної (яка $\epsilon$ носієм інформації, що направлена на споживача) $\mathrm{i}$ комунікаційної (що забезпечує дуальну спрямованість інформаційного потоку) компонентів. У своєму сукупному прояві дані компоненти маркетингу впливають на формування споживчої поведінки.

Для доказу даного положення ми вважаємо доречним звернутися до теоретичних основ дослідження маркетингових комунікацій, базисом яких є ряд теорій та концепцій (таблиця 1). Зміст таблиці демонструє, що пізнання предмета маркетингових комунікацій, їх місця і ролі в формуванні маркетингового середовища вимагає детального вивчення положень теорій i концепцій, які акцентують увагу на різних предметних областях дослідження маркетингових комунікацій, що впливає на трактування їх сутності та змісту. 


\section{Основні теорії та концепції, що формують предметні області дослідження}

Таблиця 1 маркетингових комунікацій

\begin{tabular}{|c|c|}
\hline $\begin{array}{l}\text { Назва теорії } \\
\text { (концепції) }\end{array}$ & $\begin{array}{cccc}\text { Основні положення } & \text { предметних } & \text { областей дослідження } \\
\text { маркетингових комунікацій } & & & \end{array}$ \\
\hline 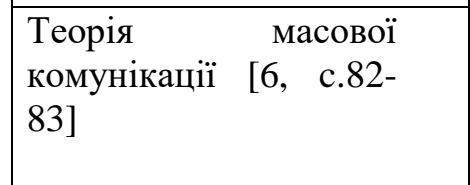 & $\begin{array}{l}\text { Визначення сутності та змісту масової комунікації, встановлення їх } \\
\text { типів, видів, каналів передачі, пояснення способів впливу засобів } \\
\text { масової інформації на цільові аудиторії в умовах стандартизованого } \\
\text { типу виробництва і споживання товарів споживчого призначення. }\end{array}$ \\
\hline $\begin{array}{l}\text { Teорії мотивації [7, с.201- } \\
\text { 210] }\end{array}$ & $\begin{array}{l}\text { Дослідження сутнісної і процесуальної природи та чинників } \\
\text { формування потреб, уявлення комунікації як обміну ринковими } \\
\text { продуктами і економічними благами, дослідження міжособистісних } \\
\text { соціальних контактів і комунікацій, механізмів мотивації } \\
\text { міжособистісних відносин, опосередкованих економічними інтересами. }\end{array}$ \\
\hline $\begin{array}{l}\text { Критична } \\
\text { комунікації [8] }\end{array}$ & $\begin{array}{l}\text { Критичний аналіз і переосмислення тенденцій соціально-економічного } \\
\text { розвитку, оцінка ролі маркетингу, визнання домінуючої ролі засобів } \\
\text { масової інформації в ідеологізації економічного розвитку суспільства в } \\
\text { інтересах правлячої еліти }\end{array}$ \\
\hline $\begin{array}{l}\text { рмаційного } \\
{[9]}\end{array}$ & $\begin{array}{l}\text { Визначення інформаційного суспільства як нової стадії розвитку } \\
\text { цивілізації, обгрунтування провідної ролі телекомунікаційних і } \\
\text { комп'ютерних засобів інформаційного обміну, пояснення інформації як } \\
\text { ринкового продукту і базової соціальної цінності }\end{array}$ \\
\hline & $\begin{array}{l}\text { Обгрунтування маркетингових комунікацій як елемента комплексу } \\
\text { маркетингу, їх функціональних завдань, ролі комунікаційної політики в } \\
\text { маркетинг-міксі, аналіз маркетингових чинників взаємовпливу } \\
\text { суб'єктів, об'єктів і каналів комунікацій }\end{array}$ \\
\hline $\begin{array}{l}\text { Tеорія } \quad \text { бренд- } \\
\text { менеджменту [11] }\end{array}$ & $\begin{array}{l}\text { Пояснення суті і змісту бренду та брендингу, вбудовування комплексу } \\
\text { маркетингових комунікацій в процес створення цінності бренду для } \\
\text { цільової аудиторії, визначення факторів формування його } \\
\text { нематеріальної природи }\end{array}$ \\
\hline $\begin{array}{l}\text { Концепція } \\
\text { маркетингових } \\
\text { комунікацій }\end{array}$ & $\begin{array}{l}\text { Визначення } \\
\text { напрямків, } \text { методів, інструментів маркетингових } \\
\text { комунікацій, принципів управління ними, розробка стратегій } \\
\text { маркетингових комунікацій, стратегічних і тактичних програм їх } \\
\text { розвитку }\end{array}$ \\
\hline $\begin{array}{l}\text { Концепція інтегрованих } \\
\text { маркетингових } \\
\text { комунікацій }\end{array}$ & $\begin{array}{l}\text { Системне уявлення маркетингових комунікацій, акцент на ефекті } \\
\text { синергії від їх застосування, взаємозв'язок стратегічного планування } \\
\text { маркетингових комунікацій } 3 \text { життєвими циклами брендів товару і } \\
\text { організації, інтегроване уявлення системи управління маркетинговими } \\
\text { комунікаціями }\end{array}$ \\
\hline $\begin{array}{l}\text { Концепція } \\
\text { відносин }\end{array}$ & $\begin{array}{l}\text { Обгрунтування пріоритету довгострокових взаємовідносин суб'єктів } \\
\text { ринку, визнання необхідності партнерської і інтерактивної їх взаємодії, } \\
\text { що забезпечується високою якістю і своєчасністю реалізації } \\
\text { маркетингових комунікацій }\end{array}$ \\
\hline
\end{tabular}

Еволюцію, яка відбувалась в комунікаційному полі підприємства, можна представити кількома етапами. В дослідженнях Багієва Г. Л. проаналізовано особливості змін маркетингових комунікацій в період становлення сучасної економіки споживання в епоху постіндустріального розвитку країн та виділено п’ять етапів формування маркетингових комунікацій: Етап 1: 1950-1960 pp. - несистемні комунікації; Етап 2: 1960-1970 pp. - товарні комунікації; Етап 3: 1970-1980 pp. - комунікації 3 
цільовими групами; Етап 4: 1980-1990 рр. - конкурентні комунікації; Етап 5: 1990 - дотепер конкурентні та інтегровані комунікації [15].

Більш поглиблено процес формування і розвитку маркетингових комунікацій розглядають в своїх дослідженнях С. Ковальчук та I. Хмарська [16, с. 557-562], які пропонують еволюціонування маркетингових комунікацій розглядати за такими етапами:

1. Емпіричний (4-3 тис. до н.е. - перша половина XII ст.).

2. Доіндустріальний (XII-XVIII ст.).

3. ндустріальний (XIX - перша половина XX ст.).

4. Несистемні комунікації (1950-1960рр.).

5. Товарні комунікації (1960-1970рр.).

6. Комунікації з цільовими групами (1970-1980 pp.).

7. Конкурентні комунікації (1980-1990рр.).

8. Конкурентні та інтегровані комунікації (1990-2010 pр.).

9. «Комунікативна пандемія» (2010 - дотепер).

Узагальнюючи інформацію щодо етапів становлення маркетингових комунікацій, можна відзначити, що маркетинг в його різноманітті контактів зі споживачами еволюціонував саме в частині вдосконалення впливу на споживче уявлення з урахуванням комплексності інструментів, підходів та інтеграції зусиль, що докладаються.

Важливим для дослідження $є$ встановлення ролі маркетингових комунікацій як маркетингового інструменту, що дає можливість впливати на формування поведінки споживача та основних стейкхолдерів.

Доказ цього впливу лежить в площині пізнання ефекту комунікації - змін в знаннях споживача (одержувача інформації), його установках (тобто в стійких уявленнях) або зміни поведінки одержувача. Ці три типи змін зазвичай відбуваються в такій послідовності: зміни в знаннях передують зміні установки, яка, в свою чергу, впливає на зміну поведінки.

Наприкінці XX століття система маркетингових комунікацій набуває нового унікального змісту в маркетингу просування товарів. Цей напрямок Д. Шульц, С. Танненбаум і Р. Лаутерборн назвали новою парадигмою маркетингу - інтегрованими маркетинговими комунікаціями (IMК). Інтегровані маркетингові комунікації - це нова концепція комунікаційного маркетингу, що була утворена в процесі розвитку економіки в кінці XX ст., та саме їй пророкують лідируючі позиції на найближчу перспективу.

За визначенням авторів концепції Д. Шульца, С. Танненбаума, Р. Лаутерборна, інтегровані маркетингові комунікації - «..це новий аналіз цілого там, де раніше ми бачили тільки окремі розрізнені складові - такі, як реклама, паблік рілейшнз, стимулювання продажів, комунікації 3 працівниками тощо. Такий підхід дозволяє скоординувати всі види комунікацій, щоб подивитись на них очами споживачів - як на потік інформації з недиференційованих джерел» [17, с. 795]. Хоча спірним залишається погляд на те, що авторами акцентовано увагу на інтегруванні інформації, а не елементів маркетингових комунікацій.

Американська асоціація рекламних агенств вважає, що інтегровані маркетингові комунікації це концепція планування маркетингових комунікацій , що виходить з розуміння необхідності оцінки стратегічної ролі окремих комунікативних елементів (реклами, стимулювання збуту, PR тощо) і їх оптимального поєднання для забезпечення послідовності i пошуку максимізації впливу комунікативних програм за допомогою несуперечливої інтеграції всіх звернень. Інтегровані маркетингові комунікації дозволяють підвищити ефективність продаж компанії, так як в сукупності просувають імідж підприємства і його торгової марки.

Концепція інтегрованих маркетингових комунікацій починається не 3 товару i послуг підприємства або компанії, а з бажань споживачів, в чому він має потребу, а потім виходячи з цього, повертається назад до продукту, бренду або організації. Тому компанія відправляє свої повідомлення, які орієнтовані не стільки на продукт, скільки на інтереси отримувача. Інтегровані маркетингові комунікації представляють більш широке концептуальне розуміння ніж комунікації маркетингу і стратегія просування. В інтегрованих маркетингових комунікаціях застосовуються технології на основі баз даних , які дозволяють визначати склад цільової аудиторії та проводити ії сегментацію для вибору найкращих медійних засобів для кожного сегменту. 
Щодо стратегії просування, то вона збільшує обсяги продажу і дозволяє досягати результативності за рахунок масштабів виробництв, при цьому «знижуючи виробничі витрати на кожну одиницю продукції, яка випускається». Більш низькі витрати дозволяють знижувати ціну і впливати на доступність продуктів для споживачів.

Інтегровані маркетингові комунікації призначені для виконання наступних задач: визначення особливостей сприйняття і оцінки споживачами продукції компанії; інтегрування стратегій бізнесу 3 потребами i видами діяльності окремого споживача; координація всіх комунікацій бізнесу 3 урахуванням повного набору маркетингових комунікацій; налагодження контакту з споживачами i перманентний діалог з ними, підбір комунікацій під уподобання окремих споживачів.

На думку Ф. Котлера, інтегровані маркетингові комунікації - це інструмент маркетингової адаптації діяльності підприємств до змін зовнішнього середовища. Автор визначає діапазон їх дії «від жорсткої прив'язки до визначених комунікативних каналів - до використання методів, що дозволяють донести до клієнта імідж торгової марки при кожному контакті з ними» [11]. На думку вченого, управління єдиним комунікаційним процесом та його координація портебують створення інтегрованих маркетингових комунікацій: такого їх планування при якому враховувались би стратегічні можливості різних інструментів комунікації та взаємодіяли таким чином, щоб забезпечити ясність, послідовність і максимальний ефект завдяки бездоганній інтеграції окремих звернень [11, с. 658].

В наукових публікаціях сучасних дослідників інтегровані маркетингові комунікації розглядаються з різних точок зору.

3 позиції сучасної маркетингової концепції, на думку Сіренко К. В., ІМК - це сучасна концепція одночасного та синергічного застосування реклами, стимулювання збуту, прямого маркетингу та Public relations, що застосовується для максимальної ефективності комунікаційної діяльності підприємства. Автори наголошують, що ця концепція потребує оцінки стратегічної ролі окремих засобів маркетингової комунікації [13, с. 80]. Розглядаючи ІМК з позиції інформаційнопсихологічного впливу на суб'єкти зовнішнього та внутрішнього середовища, Г. В. Янковська визначає, що ІМК спрямовані на досягнення основних стратегічних цілей та вирішення оперативних завдань підприємства [18]. Р. Раупов розглядає IMК з позиції комплексного підходу, наголошуючи, що максимальна ефективність взаємозв'язків між компанією та ії ринком досягається через комплекс погоджених маркетингових комунікацій [19].

Таким чином, думки великої кількості науковців збігаються в тому, що концепція інтегрованих маркетингових комунікацій полягає в забезпеченні єдиного в інформаційного сенсі, але комплексного в комунікативному сенсі впливу на споживача, що забезпечує його купівельну активність. Але важливим в практичному використанні цієї концепції $є$ по-перше, розуміння достатності маркетингової інформації, яка необхідна для прийняття рішення цільовою групою споживачів; по-друге, необхідність диференціації маркетингової інформації і каналів комунікації в залежності від типу конкурентної поведінки різних цільових груп споживачів.

Інтеграція комунікацій дозволяє підвищити ефективність їх впливу на споживачів, завоювати або зміцнити їх прихильність до торгової марки, посилити маркетингову комунікаційну програму, яка проводиться підприємством і в результаті може впливати на ефективність функціонування $\mathrm{i}$ розвитку компанії - ініціатора комунікації. Але серед вчених-теоретиків немає єдиного погляду стосовно результативності і ефективності комунікаційного процесу, який забезпечується певною сукупністю маркетингових комунікацій.

На думку Є. В. Солдатової та Є.І. Кручиніної, підвищення ефективності маркетингових комунікацій при їх інтеграції обумовлена наступними причинами:

-проводиться загальне фінансування при формуванні бюджетів різних комунікативних засобів, що дає можливість усунути конфлікт в системі управління маркетингом;

-з’являється «центр управління» по просуванню продукції;

-проводиться єдине планування комунікаційної компанії і усувається негативний ефект від розсилки різних і найчастіше, суперечливих повідомлень про продукт компанії;

- скорочуються витрати порівняно з традиційним використанням.

В результаті використання інтегрованих маркетингових комунікацій можлива суттєва економія, так як вони дозволяють відмовитися від прямого розміщення реклами на телебаченні [20]. Цей авторський посил науковців $\epsilon$, скоріше, теоретичним тезисом, ніж доведеним фактом. Так як поки що відсутні дослідження які б порівнювали ефективність різних комбінацій маркетингових комунікацій 
в інформаційному і економічному аспектах. Саме факт відсутності подібних досліджень стримує пошук раціональних підходів до інтегрування комунікативних інструментів в ринковому просторі.

Відсутність таких підходів, по перше, не дозволяє підприємству, яке виступає ініціатором побудови необхідного йому комунікаційного простору, мінімізувати витрати на інтегровані комунікації, по - друге, сформувати умови і створити передумови для вибору такого набору маркетингових комунікацій, які б виступали ключовим інструментом в конкурентній стратегії розвитку підприємства. Ще однією слабкою стороною IMК є те, що мається на увазі здійснення інтеграції тільки на рівні комунікаційних інструментів, не враховуючи при цьому склад учасників взаємодії та їх характеристики (мотиваційні, ресурсні, організаційні, технічні, інноваційні). Інтеграція повинна була б співвіднесена 3 інтеграцією мотивів всіх стекхолдерів, їх ресурсів, станом ринку i конкретного комунікаційного простору.

Одним 3 головних переваг використання інтегрованих маркетингових комунікацій $є$ ефект синергії, узгоджені між собою рекламні, маркетингові, PR-повідомлення мають більший вплив ніж дія кожного окремого напрямку. Автор погоджується 3 думкою Примак Т. О., яка в своїх дослідженнях виокремлює три рівня прояву і посилення синергетичного ефекту: ефект від взаємодії структурних елементів одного маркетингового повідомлення; ефект від комплексного використання інструментів маркетингових комунікацій; ефект від дії комунікаційних ресурсів всіх елементів системи управління ринковою діяльністю підприємства [21].

Таким чином, говорячи про постійні контакти двох ключових суб’єктів на ринку (споживача і виробника), слід наголосити, що всі вони виникають і концентруються в маркетинговій площині. Акцент у маркетингу переноситься від взаємовідносин з окремими споживачами на розробку і підтримку ефективних взаємовідносин з постачальниками, дистриб'юторами, ритейлерами та іншими партерами компанії.

Висновки. Посилення конкуренції на ринках та пов'язана з цим необхідність впровадження продукції, що має конкурентні переваги, породжує появу нових засобів конкурентної боротьби [22, c.8]. Маркетинг в частині вдосконалення впливу на споживче уявлення з урахуванням комплексності інструментів, підходів та інтеграції зусиль, які докладаються, останній часом зазнав значних змін. Відбувся своєрідний перерозподіл ролі елементів маркетингу на користь зростання інформаційної і комунікаційної компонентів. Маркетингові комунікації є основою формування стійкого позитивного іміжду підприємства та дають можливість впливати на формування поведінки споживача та основних стейкхолдерів. Доказ цього впливу лежить в площині пізнання ефекту комунікації - змін в знаннях споживача (одержувача інформації), його установках (тобто в стійких уявленнях) або зміни поведінки одержувача. Ці три типи змін звичайно відбуваються в такій послідовності: зміни в знаннях передують зміни установки, яка, в свою чергу, впливає на зміну поведінки.

Інтегровані маркетингові комунікації це своєрідний набір інструментів, який дозволяє «координувати всі стимулюючі види діяльності: медійну рекламу, прямі і поштові розсилки, особистий продаж, стимулювання продаж і паблік рілейшнз, щоб в підсумку отримати уніфіковане стимулююче повідомлення 3 цілеспрямованою дією на споживача. Одним 3 головних переваг використання інтегрованих маркетингових комунікацій є ефект синергії, узгоджені між собою рекламні, маркетингові, PR-повідомлення мають більший вплив ніж дія кожного окремого напрямку. Інтеграція комунікацій дозволяє підвищити ефективність їх впливу на споживачів, завоювати або зміцнити їх прихильність до торгової марки, посилити маркетингову комунікаційну програму, яка проводиться підприємством і в результаті може впливати на ефективність функціонування і розвитку компанії - ініціатора комунікації.

\section{Список використаних джерел}

1. Етимологічний словник української мови: у 7 т. / гол. ред. О. С. Мельничук. Київ: Наук. думка, 1985. Т. 2. $572 \mathrm{c}$.

2. Завадський Й. С. Менеджмент. Київ: Вид-во Свроп. ун-ту, 2003. 640 с.

3. Почепцов Г. Г. Теория коммуникаций. Москва: Реалбук; Київ: Ваклер, 2001. 656 с.

4. Карпенко Н. В., Яловега Н. І. Комплекс маркетингових комунікацій у стратегічному управлінні маркетинговою діяльністю підприємства: монографія. Полтава: ПУЕТ, 2012. 278 с.

5. Дуцик Д. Р. Політична журналістика. Київ: ВД «Києво-Могилянська академія», 2005. 138 с.

6. Мак-Квейл Д. Теорія масової комунікації / пер. з англ. О. Возьна, Г. Сташків. Львів: Літопис, 2010. C. $82-83$. 
7. Мачтакова О. Г. Мотивація: від античності до постмодернізму: монографія. Одеса: Атлант, 2013.210 с.

8. Медиа и революция. Критическая теория общества. Технология и власть. Гуманитарный портал. URL: http://www.dxlab.org/ru/lectures/lecture5.htm

9. Ожеван М.Л., Піскорська Г. Л. Глобальне інформаційне суспільство. Украӥнська дипломатична енциклопедія: у 2-х т. / редкол.: Л. В. Губерський та ін. Київ: Знання України, 2004. Т. 1. 760 с.

10. Samli A. C., Jermakowicz W. The Stages of Marketing Evolution in East European Countries. Europen Jounal of Marketing. 1983. V. 17. No. 2. P. 26-33.

11. Котлер Ф. Маркетинг менеджмент / пер. с англ. под ред. Л. Волковой, Ю. Н. Каптуревского. СПб: Питер, 2001. 752 с.

12. Burnett J., Moriarty S. Introduction to Marketing Communications: An Integrated Approach. Upper Saddle River NJ: Prentice Hall, 2000. 208 p.

13. Сіренко К. В. Аналіз змістовного наповнення категорії «інтегровані маркетингові комунікації». Управління розвитком. 2011. № 4 (10). С. 227-228.

14. Примак Т. Від маркетингу відносин до маркетингу утримування клієнтів. Маркетинг в Україні. 2006. № 3. С. 42-44.

15. Багиев Г. Л., Тарасевич В. М., Анн Х. Маркетинг. Москва: ЗАО «Изд-во Экономика», 2001. С. 465.

16. Хмарська I. А. Етапізація процесу формування маркетингових комунікацій. Економіка $i$ суспільство. 2018. Вип. 14. С. 554-563.

17. Шульц Д. Е., Танненбаум С. И., Лаутерборн Р. Ф. Новая парадигма маркетинга: интегрируемые маркетинговые коммуникации. Москва: Инфра-М, 2004.

18. Янковська Г. В. Сутність маркетингових комунікацій та їх місце у системі маркетингу. Наука ц̌ економіка. 2010. № 4 (20). С. 98-101.

19. Раупов Р. Б. Інтеграція маркетингових комунікацій. Вісник Хмельницького національного університету. 2009. № 6. C. 85-89.

20. Кручинина Е. И., Солдатова Е. В. Концепция интегрированных маркетинговых коммуникаций. Системное управление. 2013. № 14. С. 68-77.

21. Примак Т. О. Маркетингові комунікації в системі управління ринковою діяльністю підприємства: дис... д-ра екон. наук: 08.06.01 / Київський національний економічний ун-т. Київ, 2004.

22. Коломицева О., Боковня А., Бурцева Т. Використання маркетингових комунікаційних технологій в інноваційному розвитку підприємств. Збірник наукових пращь Черкаського державного технологічного університету. Серія: Економічні науки. 2016. Вип. 42 (2). С. 5-13.

\section{References}

1. Etymological dictionary of the Ukrainian language (1985) in 7 vol. / Editor in Chief. O. S. Melnychuk. Kyiv: Scientific Thought, vol. 2 [in Ukrainian].

2. Zavadskyi, Y. S. (2003) Management. Kyiv: European University Publishing House [in Ukrainian].

3. Pocheptsov, H. H. (2001) Communication Theory. Moscow: Realbook; Kyiv: Vakler. [in Russian].

4. Karpenko, N. V., Yaloveha, N. I. (2012) A complex of marketing communications for strategic management of marketing communications: monograph. Poltava: PUET [in Ukrainian].

5. Dutsyk, D. R. (2005) Political Journalism. Kyiv: publishing house "Kyiv-Mohyla Academy" [in Ukrainian].

6. McQuail, D. (2010) Theory of Mass Communication / Translated from English by O. Vozna, G. Stashkiv. Lviv: Litopys, 2010 [in Ukrainian].

7. Machtakova, O. H. (2013) Motivation: from antiquity to postmodernism: monograph. Odessa: Atlant [in Ukrainian].

8. Media and revolution. Critical theory of society. Technology and power. (2019) Humanitarian portal. Available from: http://www.dxlab.org/ru/lectures/lecture5.htm [5 November, 2019] [in Russian].

9. Ozhevan, M. L., Piskorska, H. L. (2004) Global Information Society. Ukrainian Diplomatic Encyclopedia: in 2 vol. /Editorial collegium.: L. V. Huberskyi and other. Kyiv: Knowledge of Ukraine, vol. 1, 760 p. [in Ukrainian].

10. Samli, A. C., Jermakowicz, W. (1983) The Stages of Marketing Evolution in East European Countries. Europen Jounal of Marketing, vol. 17, no. 2, p. 26-33.

11. Kotler, F. (2001) Marketing management / Translated from English by L. Volkova, Yu. Kapturevskyi. Saint Petersburg: Pyter [in Russian].

12. Burnett, J., Moriarty, S. (2000) Introduction to Marketing Communications: An Integrated Approach. Upper Saddle River NJ: Prentice Hall.

13. Sirenko, K. V. (2011) Content analysis of the category «integrated marketing communications». Development Management, no. 4 (10), pp. 227-228 [in Ukrainian].

14. Prymak, T. (2006) From relationship marketing to customer retention marketing. Marketing in Ukraine, no. 3 , pp. 42-44 [in Ukrainian]. 
15. Bahyev, H. L. Tarasevych, V. M. Ann, Kh. (2006) Marketing. Moscow: Economics Publishing House [in Russian].

16. Khmarska, I. A. (2018) Staging the process of forming marketing communications. Economy and society, vol. 14, pp. 554-563 [in Ukrainian].

17. Shults, D. E., Tannenbaum, S. I., \& Lauterborn, R. F. (2004) The new paradigm of marketing. Integrable marketing communications. Moscow: Infra-M [in Russian].

18. Yankovska, H. V. (2010) The essence of marketing communications and their place in the marketing system. Science and economics, no. 4 (20), pp. 98-101 [in Ukrainian].

19. Raupov, R. B. (2009) Integration of marketing communications. Bulletin of Khmelnitsky National University, no. 6, pp. 85-89 [in Ukrainian].

20. Kruchinina, E. I., Soldatova E. V. (2013) The concept of integrated marketing communications. System management, no. 14, pp. 68-77 [in Russian].

21. Prymak, T. (2004) Marketing communications in the enterprise market management system: dissertation [Marketynhovi komunikatsii $\mathrm{v}$ systemi upravlinnia rynkovoiu diialnistiu pidpryiemstva: dys... d-ra ekon. nauk: 08.06.01] Kyiv National Economic University. Kyiv [in Ukrainian].

22. Kolomytseva, O. Bokovnia, A. Burtseva, T. (2006) Use of marketing communication technologies in innovative development of enterprises. Zbirnyk naukovykh prats Cherkaskoho derzhavnoho tekhnolohichnoho universytetu. Seriia: Ekonomichni nauky, vol. 42 (2), pp. 5-13.

\title{
L.S. Vasylchenko
}

\section{ENTERPRISE MARKETING COMMUNICATIONS: GENESIS AND STAGE STAGES}

\begin{abstract}
After quite a long period in its development, modern marketing has developed into a recognized theory of effective economic activity in a competitive environment and a system of meeting the needs of the market, which is a required practice. Expanding its boundaries and scope leads to a new filling of the content of the marketing category, changes of objects and subjects and improvement of tools, and the rational interaction of subjects in the market space cannot be ensured without well-established elements of communication. The etymology of the concept of "communication" is analyzed in the article and various approaches and definitions of this definition are explored. It is established that a special place among mass communications is marketing communications, which represent the process of transferring information about a product and its properties directly to the target audience. The paper presents the basic theories and concepts that form the subject areas of marketing communications research, explores a new concept of communication marketing - integrated marketing communications, which is a tool for marketing adaptation of business activity to changes in the environment. The reasons of increase of efficiency of marketing communications at their integration are also characterized, the main advantages of use of integrated marketing communications are given. The purpose of the article is to study the stages of formation of integrated marketing communications, the object - the process of formation and development of integrated marketing communications enterprise. The analysis of the existing theoretical views on the essence of marketing communications has led to the conclusion that there is a need for new theoretical and methodological approaches to solving the problem of interconnection of marketing communications and the enterprise activity management system. The development of market relations of the domestic economy requires new, adequate requirements of the present forms and methods of interaction of the enterprise with external and internal environments. The prospect of further research is to find rational approaches to integrating communication tools in the market space.
\end{abstract}

Keywords: communications, marketing communications, integrated marketing communications, evolution of marketing communications, stages of formation of marketing communications.

Стаття надійшла до редакції 03.11.2019

DOI 10.24025/2306-4420.0.55.2019.187527 